\title{
The Toxicity of Tobacco Smoke Solutions to Proteus Vulgaris*
}

\author{
by P. W. Brown and C. A. Fowler \\ Carreras Limited, Research Division, Basildon, England
}

INTRODUCTION

Several workers have investigated the biological effects of cigarette smoke with respect to ciliastatic activity $(2,10)$ and toxicity $(6,8,9)$. Our aim in this laboratory was to develop a rapid and accurate biological test for the toxic nature of tobacco smoke, in addition to employing the more sophisticated and lengthy techniques, such as described by some of the above authors.

Wang (8) found Paramecium aurelia very sensitive to tobacco smoke toxins. Weiss and Weiss (9) confirmed these results finding also that cigarettes with charcoal filters attached produced smoke solutions that were almost as toxic to Paramecium aurelia as the smoke solution from a non-filter brand and that high concentrations of phenol and nicotine were required to reproduce the effect of smoke solutions. Thayer and Kensler (6) have shown that water soluble components of total cigarette smoke inhibit cell growth in a culture of $\mathrm{K}$. B. human cells. Filters of activated charcoal granules reduced the concentration of cytotoxins in tobacco smoke, being most effective for the gas phase.

Turkheim (7) reported bacteriostatic properties of tobacco smoke working with Bacillus subtilis and Escherichia coli. Audier (1) found tobacco smoke and condensate to be incompletely bacteriostatic towards Lactobacillus lactis and Staphylococcus aureus. References have been made by various authors to the bacteriostatic or bacteriocidal effects of tobacco smoke on other species including Pseudomonas aeruginosa, Salmonella typhosa, Serratia marcescens, Streptococcus pyogenes (5). The susceptibility of these micro-organisms appears to vary, although the variation in response could be related to the experimental conditions in addition to the bacterial species.

It was decided to investigate the possible use of bacteria for the rapid bioassay of smoke solutions. Our intention is to carry out similar work using cultures of mammalian cells with the aim of comparing bacterial and mammalian systems.

TABLE 1

Comparison of "total" smoke solution with "gas" phase smoke solution

\begin{tabular}{l|c|c|c}
\hline $\begin{array}{l}\text { Description of } \\
\text { smoke solution }\end{array}$ & $\begin{array}{c}\text { Volume of } \\
\text { smoke solution } \\
\text { used } \\
\text { (mls.) }\end{array}$ & $\begin{array}{c}\text { Percentage } \\
\text { difference } \\
\text { from control } \\
\text { (mean) }\end{array}$ & Range \\
\hline Trapped smoke & 0.1 & -28.4 & -21.1 to -50.0 \\
from & 0.5 & -52.6 & -50.0 to -57.3 \\
10 cigarettes & 1.0 & -56.2 & -48.0 to -62.3 \\
unfiltered & & & \\
\hline $\begin{array}{l}\text { Trapped smoke } \\
\text { from }\end{array}$ & 0.1 & -28.1 & -17.6 to -50.0 \\
10 cigarettes & 0.5 & -51.1 & -43.3 to -65.8 \\
filtered through & 1.0 & -56.9 & -47.6 to -65.8 \\
$\begin{array}{l}\text { Cambridge } \\
\text { filter }\end{array}$ & & & \\
\hline
\end{tabular}

(incubation time: 2 hours)

\section{MATERIALS AND METHODS}

Smoke solutions used in the test system were prepared using a Cigarette Components Limited cigarette smoking machine. Two $100 \mathrm{ml}$. round bottom flasks each containing $50 \mathrm{ml}$. of distilled water at room temperature were connected in series and placed on a shaker. One end of this trapping system was connected to the smoking machine whilst the other end was connected to a Cambridge

\footnotetext{
* Received for publication: 20th July, 1967.
} 


\begin{tabular}{cc|c}
\hline $\begin{array}{c}\text { Amount of } \\
\text { compound } \\
\text { per flask } \\
(5 \mathrm{ml} .)\end{array}$ & $\begin{array}{c}\text { Percentage } \\
\text { difference from } \\
\text { control }\end{array}$ & $\begin{array}{c}\text { Theoretical amount in } \\
1 \text { ml. of smoke solution } \\
\text { from 10 cigarettes } \\
\text { assuming } 100 \% \text { recovery }\end{array}$ \\
\hline Phenol & $30 \mu \mathrm{g}$. & $\mathrm{Nil}$ \\
$60 \mu \mathrm{g}$. & $\mathrm{Nil}$ \\
$100 \mu \mathrm{g}$. & $\mathrm{Nil}$ \\
$200 \mu \mathrm{g}$. & $\mathrm{Nil}$ & \\
Nicotine & $\begin{array}{c}0.20 \mathrm{mg} . \\
0.25 \mathrm{mg} .\end{array}$ & $\mathrm{Nil}$ \\
$0.50 \mathrm{mg}$. & $\mathrm{Nil}$ & \\
$1.00 \mathrm{mg}$. & -8.2 & \\
$2.00 \mathrm{mg}$. & -8.2 & \\
$5.00 \mathrm{mg}$. & -12.3 & \\
$10.00 \mathrm{mg}$. & -28.3 & \\
\hline
\end{tabular}

(incubation time: 2 hours)
TABLE 2

Toxicity of phenol and nicotine solutions to Profeus vulgaris

filter holder. Cigarettes were smoked using a $35 \mathrm{ml}$. puff volume of two-second duration at fifty-eightsecond intervals to a butt length of $23 \mathrm{~mm}$. The contents of the flasks were combined and used as the smoke solution. An over-night culture of Proteus vulgaris was centrifuged for five minutes. After pouring off the supernatant the cells were resuspended in distilled water. By appropriate dilution of the suspension a concentration

was obtained which when diluted $1: 5$ had an optical density of 0.400 at $450 \mathrm{~m} \mu$ using I cm. cells. $1 \mathrm{ml}$. of this bacterial suspension, $1 \mathrm{ml}$. of phosphate buffer $\mathrm{pH} 7.0$ and $1 \mathrm{ml}$. of glucose-peptone broth were placed in a Warburg flask together with the requisite volume of smoke solution. The final volume was adjusted to $5 \mathrm{ml}$. with distilled water. The flask with contents was allowed to stand for exactly fifteen minutes. The $\mathrm{pH}$ of the flask contents before incubation was checked using a duplicate solution.

The flask was then placed on the Warburg apparatus and incubated at $37^{\circ} \mathrm{C}$ for two hours. The use of the Warburg apparatus for incubation was a matter of convenience in this laboratory. After incubation the resulting culture was diluted $I$ in 5 , with distilled water and the optical density measured on a Unicam S. P. 500 at $450 \mathrm{m \mu}$ using $I \mathrm{~cm}$. cells. A control flask in which smoke solution was replaced by an equal volume of water was treated in the same way as the assay flasks.

The percentage difference in optical density between the test flask and the control flask was a measure of the toxicity. In this way the toxicity of various smoke solutions was compared.

\section{RESULTS}

An initial study was carried out to compare the effect of smoke solutions prepared in two different ways. The first solution was prepared by smoking a total of ten cigarettes of a commercially available brand without filters using the trapping system described. The second solution was produced using the same brand of cigarettes, this time, however, a Cambridge filter pad was inserted in the holder and thus only the gas phase components of the smoke were collected. As can be seen from Table $I$ results obtained from the two solutions using $0.1 \mathrm{ml}$., $0.5 \mathrm{ml}$., and $1.0 \mathrm{ml}$, aliquots show that there is little difference in their toxicity. This particular result was of interest in that it indicated that the cytotoxins were present in the gas phase only, the particulate phase of the smoke (material retained by the Cambridge filter pad) appearing to be inactive. Results of experiments carried out to investigate the toxicity of phenol and nicotine, two major components of the particulate phase, show these compounds to be relatively inactive in concentration similar to those found in smoke (see Table 2). This observation would partially confirm the results obtained with the two smoke solutions and is in agreement with work carried out by Weiss and Weiss (9) using Paramecium aurelia and by Thayer and Kensler (6) using cultures of K. B. human cells who showed phenol and nicotine to possess little activity. Subsequent work was entirely concerned with the gas phase of cigarette smoke and some of its components. The efficiency of various, carbon loadings in removing cytotoxins from tobacco smoke using recess filters was investigated. The carbon used was supplied by Sutcliffe Speakman and Company Limited (Grade C. R. 26) and was activated before use. In preparing the smoke solutions the smoke was passed through a Cambridge filter so that only the removal of substances from the 


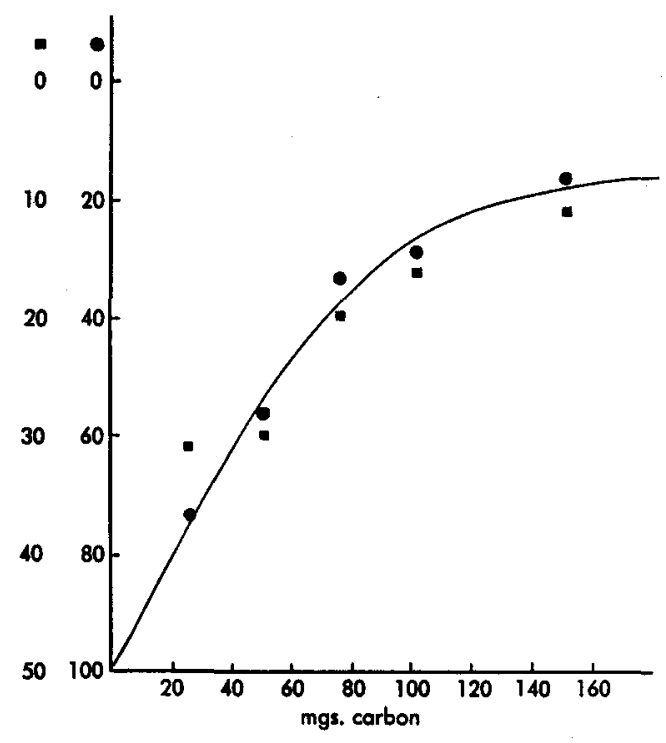

FIGURE 1

Reduction in toxicity and total aldehyde content of smoke solutions using various carbon loadings conlained in recess filters

Percentage reduction in growth as compared with control

- Percentage aldehyde content in smoke solution as compared with solution from "total vapour phase smoke solution"

(10 cigarettes smoked into $100 \mathrm{mls}$. of distilled water vapour phase only, 2 hours incubation)

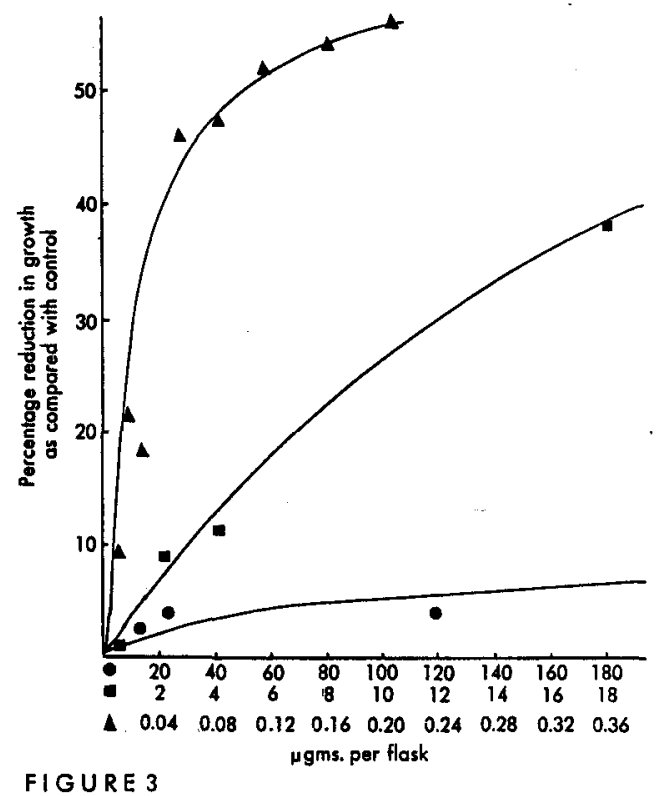

Toxicity of pure compounds to Proteus vulgaris

cyanide (as KCN)

$\triangle$ acroleín

acetaldehyde

(2 hours incubation)

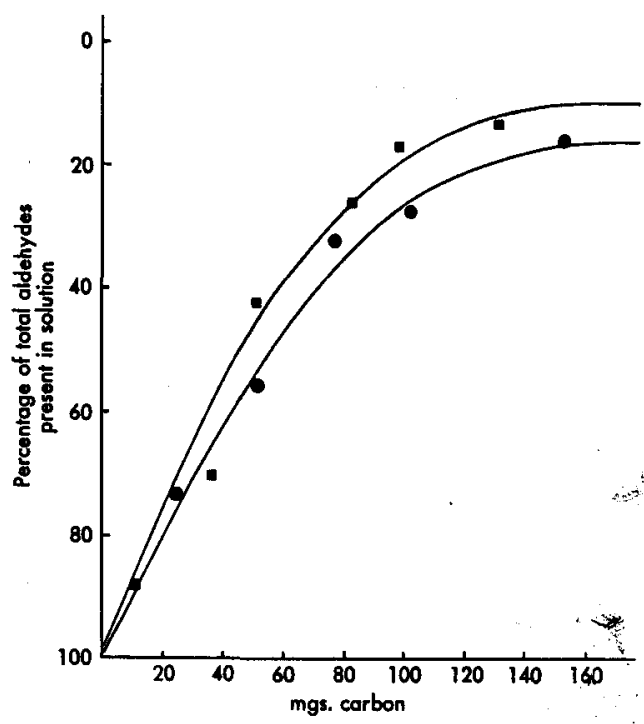

FIGURE 2

Comparison of toxicity trapping systems with conventional trapping system ( -200 C) using various carbon

Toxicity trapping system

Conventional trapping system $(-200 \mathrm{C})$ expressed as percentage of total aldehydes present in solution

(10 cigarettes smoked into $100 \mathrm{~m} / \mathrm{s}$. of distilled water vapour phase only, 2 hours incubation)

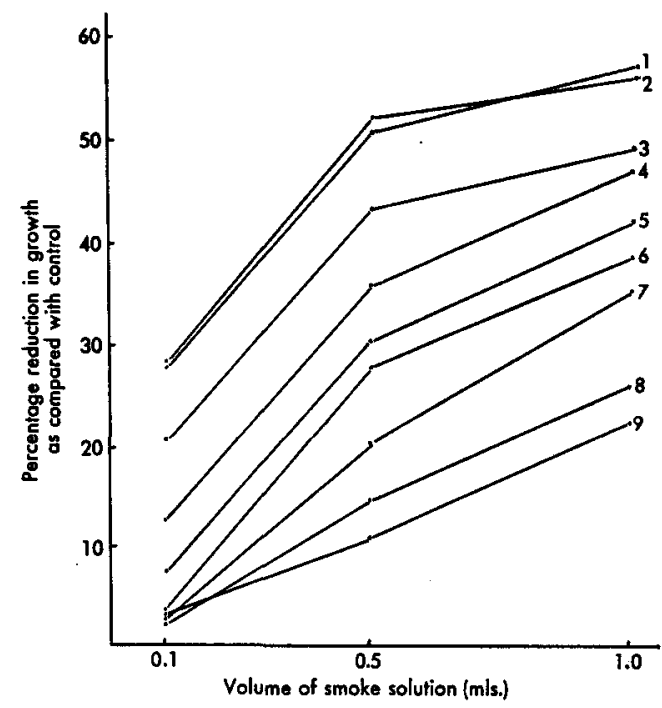

FIGURE 4

Summary of toxicity results obtained using various fltering srstems

1. Cigarette smoke through Cambridge filter

2. Unfiltered cigarette smoke

3. Carbon filter type A

4. Carbon filter type $B$

5. $25 \mathrm{mgs}$, carbon in recess filter

6. $50 \mathrm{mgs}$. carbon in recess filter

7. $75 \mathrm{mgs}$. carbon in recess filter

8. 100 mgs. carbon in recess filter

9. $150 \mathrm{mgs}$. carbon in recess filter

(10 cigarettes smoked into $100 \mathrm{mls}$. of distilled water vapour phase only, except No. 2, 2 hours incubation) 
TABLE 3

Toxicity of cigarette smoke passed through various amounts of carbon contained in recess filters

(10 cigarettes smoked into $100 \mathrm{~m} / \mathrm{s}$. of

distilled water -
vapour phase of smoke only)

gas phase was assessed. From the results shown in Table 3 it can be seen that carbon is effective in removing cytotoxins of tobacco smoke. Increasing amounts of carbon remove increasing amounts of cytotoxic material. The relationship is, however, non-linear in that as carbon loading is increased the additional amount of cytotoxin removed becomes progressively smaller. Aldehyde determinations were carried out on all solutions produced, together with an estimation of the total aldehyde content of a solution derived from the smoke of plain cigarettes passed through a Cambridge filter. Reduction in toxicity is seen (Fig. I) to be closely related to the effectiveness of carbon in reducing total aldehyde. This could be a direct relationship or indirect in that cytotoxins are removed from smoke in a similar manner to aldehydic substances.

It was of interest to compare the toxicity trapping system with more conventional systems. Aldehyde determinations were carried out on smoke solutions obtained by collecting the majority of the gas phase in acetone contained in a trapping vessel and cooled to $-20^{\circ} \mathrm{C}$. The two series of determinations (Fig. 2) are similar. However, there is some divergence at higher amounts of carbon. The trapping systems used for toxicity testing would be somewhat selective in that the most volatile components would not be recovered. The figure for unfiltered smoke is somewhat lower than for the more efficient trapping systems and would also contain a higher proportion of the less volatile aldehydes. These less volatile compounds would not be adsorbed as efficiently by carbon and thus filtration efficiency figures would be proportionately lower.

In order to compare the performance of two filters used in the production of two commercially available carbon filter cigarettes, solutions were prepared by attaching the carbon filters to cigarettes as used in previous tests. The result of the toxicity tests are shown in Table 4 together with descriptions of the filters studied.

The figures are in agreement with those obtained with various carbon loaded filters and point to the usefulness of this test in the biological assessment of filters with respect to the removal of substances from the vapour phase of tobacco smoke.

TABLE 4

Reduction of toxicity by two commercially available carbon filters

(10 cigarettes smoked into $100 \mathrm{ml}$. of distilled water vapour phase of smoke only

\begin{tabular}{c|c|c|c}
\hline $\begin{array}{c}\text { Description of } \\
\text { filter }\end{array}$ & $\begin{array}{c}\text { Volume } \\
\text { of smoke } \\
\text { solution } \\
\text { used } \\
\text { (mls.) }\end{array}$ & $\begin{array}{c}\text { Percentage } \\
\text { difference } \\
\text { from control } \\
\text { (mean) }\end{array}$ & Range \\
\hline
\end{tabular}

\section{Type A}

White crepe paper plus dusted crepe paper

(5 mg. carbon per filter)

Type B

$\begin{array}{llll}\text { Carbon triple } & 0.1 & -13.3 & -3.0 \text { to }-20.0 \\ \text { filter } & 0.5 & -36.2 & -27.3 \text { to }-44.0 \\ \text { (38 mg. carbon } & 1.0 & -47.5 & -39.4 \text { to }-53.4 \\ \text { per filter) } & & \end{array}$


Toxicity figures for various components of cigarette smoke together with levels of these compounds found in smoke solutions

\begin{tabular}{l|c|c|c}
\hline Component & $\begin{array}{c}\text { (A) } * \\
\text { Calculated } \\
\text { concentration in } \\
\text { smoke solution } \\
\text { assuming 100\% } \\
\text { retention }\end{array}$ & $\begin{array}{c}\text { Reduction in } \\
\text { growth at } \\
\text { level (A) } \\
(1 \mathrm{ml} \text { ) }\end{array}$ & $\begin{array}{c}\text { Actual } \\
\text { concentration } \\
\text { in smoke } \\
\text { solution }\end{array}$ \\
\hline $\begin{array}{l}\text { Total aldehyde } \\
\text { lacetaldehyde }\end{array}$ & $115 \mu \mathrm{g} . / \mathrm{ml}$. & $\begin{array}{c}-4.2 \\
\text { (as acetalde- } \\
\text { hyde) } \\
\text { approx. } 80 \% \text { ) }\end{array}$ & $92.5 \mu \mathrm{g} . / \mathrm{ml}$. \\
$\begin{array}{l}\text { Cyanide ion } \\
\text { Acrolein }\end{array}$ & $\begin{array}{c}\text { - } 39.0 \\
\text { Highly toxic } / \mathrm{ml} .\end{array}$ & $\begin{array}{c}\text { Not estimated } \\
\text { (see Fig. 3) }\end{array}$ \\
\hline
\end{tabular}

* 10 cigarettes smaked into $100 \mathrm{~m} / \mathrm{s}$. of distilled water -

vapour phase of smoke solution only
With a view to identifying the active components of the vapour phase of cigarette smoke, the toxicity of various compounds was examined at levels similar to those found in cigarette smoke. As can be seen from Figure 3, acrolein is highly toxic to Proteus vulgaris, cyanide (added as potassium cyanide) is moderately so, whilst acetaldehyde shows a relatively low toxicity. Table 5 is a summary of the results obtained using various components of cigarette smoke together with the amounts of these substances present in the

whole cigarette smoke and also, where estimated, the concentration of these substances in the smoke solution produced for the toxicity test.

\section{DISCUSSION}

The possible presence of cytotoxins in tobacco smoke active in respect of Proteus vulgaris has been investigated with a view to developing a rapid bioassay technique. The particulate phase of smoke appears to be inactive, an observation which is in accord with the low toxicity of phenol and nicotine demonstrated. The latter results are similar to those of Weiss and Weiss (9) using Paramecium and Thayer and Kensler (6) who studied the effect of water soluble compounds of cigarette smoke on cultures of $\mathrm{K}$. B. human cells. The test is thus most suitable for the examination of the gas phase of tobacco smoke with particular reference to the reduction in toxicity by the use of carbon filters. Very close agreement is observed between chemical determinations on smoke after filtration and the toxicity figures with respect to Proteus vulgaris. Figure 4 summarises the results of toxicity tests on smoke solutions derived from smoke which has been passed through various carbon filters. With increased carbon loadings a progressive decrease in toxicity is observed.

Specific cytotoxins in tobacco smoke have not yet been identified. Acrolein, however, in pure solution appears to be highly toxic. This component is extremely irritant and has been found to have ciliastatic properties by various workers $(9,10)$. Cyanide is reported as being ciliastatic (9) and is shown to be moderately toxic to Proteus vulgaris. The toxicity effect thus exhibits similarities with the ciliastatic properties of some smoke components. This is not surprising as it is considered that some ciliastatic agents act by inhibition of respiratory enzyme systems. Any substance acting in this way would inhibit the growth of aerobic organisms.

It is not intended that the work described above should be related directly to smoking in the human subject. The toxicity testing regime, however, gives results consistent with the ciliastatic effect of cigarette smoke, shows very good agreement with chemical evaluations of filtration efficiency, is extremely simple to operate and gives reproducible results. The authors thus believe this bioassay technique to be a useful screening test for the relative toxicity of cigarette smoke and the evaluation of various filtering systems.

Investigations are continuing in order to identify the biologically active components of cigarette smoke, the biochemical mechanisms involved and the effect of smoke on other bacterial species. Differential response to the various cytotoxins by individual species could lead to the differential bioassay of these substances present in smoke. It is intended that a system be constructed whereby fresh whole smoke can be introduced into the culture vessel thus obviating the disadvantages of our present trapping method. Mammalian tissue culture studies will be carried out in a similar manner to the above experiments with the object of directly comparing bacterial and mammalian systems. 
The highly toxic property of acrolein, a compound well known for its irritant action, has been demonstrated. It would be of interest to examine biochemical correlations between irritancy and toxicity using the above systems.

SUMMARY

The toxicity of various smoke solutions was evaluated by studying their effects on the growth rate of Proteus vulgaris. The particulate phase of smoke was shown to be inactive, a finding which was in agreement with the low toxicity observed with phenol and nicotine solutions. Tobacco smoke passed through recess filters containing either $25,50,75,100$ or $150 \mathrm{mgs}$. of carbon showed a progressive decrease in toxicity as the amount of carbon was increased. Pure compounds were evaluated in amounts similar to those found in tobacco smoke. Acetaldehyde exhibited low activity, cyanide ion moderate activity whilst acrolein was shown to be highly toxic. A rapid and reproducible bioassay method is described.

\section{ZUSAMMENFASSUNG}

Die toxische Wirkung verschiedener Lösungen von Tabakrauch in destilliertem Wasser wurde an der Wirkung auf das Wachstum von Proteus vulgaris untersucht. Die Partikelphase des Rauches erwies sich als unwirksam; dieser Befund stimmt mit der beobachteten geringen Toxizität von Phenolund Nikotinlösungen überein. Tabakrauch, der Rezeßfilter mit 25, 50, 75, 100 oder $150 \mathrm{mg}$ Kohle passiert hatte, zeigte eine Abnahme der toxischen Wirkung, die mit der Erhöhung des Zusatzes von Kohle zunahm. Mit dem gleichen Verfahren wurden reine chemische Verbindungen in Mengen geprüft, wie sie im Tabakrauch vorliegen. Acetaldehyd wies eine geringe und Cyanid eine mäßige Aktivität auf. Akrolein war dagegen stark toxisch. Die Ausführung der Methode ist einfach und schnell reproduzierbar.

RESSUME

La toxicité de solutions différentes de fumée de tabac en eau distillée a été étudiée du point de vue de l'influence exercée sur la croissance de Proteus vulgaris. La phase particulaire de la fumée se montrait inactive ce qui correspond aux effets faiblement toxiques produits par des solutions de nicotine et de phénols. La fumée de tabac ayant été passée à travers des filtres contenant respectivement $25,50,75,100$ ou $150 \mathrm{mg}$ de charbon montrait une toxicité qui diminuait progressivement avec l'élévation de la quantité de charbon ajoutée. Des composés purs ont été examinés moyennant le même procédé. Les quantités des composants en expérience étaient égales à celles présentes dans la fumée de tabac. Il s'avérait que l'aldéhyde acétique avait une activité faible, le cyanure une activité médiocre et l'acroleïne, par contre, une activité fortement toxique. L'exécution de la méthode décrite est facile et reproductible.

1. Audier, A. G.: Tijdschr. Tandheelk. 57 (1950) 841.

REFERENCES

2. Falk, H. I., Kotin, P., and Rowlette, W.: Ann. N. Y. Acad. Sci. 106, Art. 2 (1963) 583.

3. Guillerm, R., Badre, R., and Vignon, B.: Bull. Acad. Nat. Med. 20 (1961) 416.

4. Kensler, C. J., and Battista, S. P.: New Eng. J. Med. 269 (1963) 1161.

5. Larson, P. S., Haag, H. B., and Silvette, H.: Tobacco, Experimental and Clinical Studies, Williams and Wilkins 1961, p. 428-430.

6. Thayer, P. A., and Kensler, C. J.: Sci. 146 (1964) 642.

7. Turheim, H. G.: J. Dental Res. 1952, 326.

8. Wang, H.: Nature 197 (1963) 946.

9. Weiss, W., and Weiss, W. A.: Arch. Environ. Health 9 (1964) 500.

ro. Wynder, E. L., Kaiser, H. E., Goodman, D. A., and Hoffmann, D. H.: Cancer 16 (1963) 1227.

Acknowledgement

The authors would like to thank the Directors of Carreras Limited for permission to publish this work.

Authors' address:

Carreras Limited, Research Division, Nevendon Road, Basildon, Essex, England 